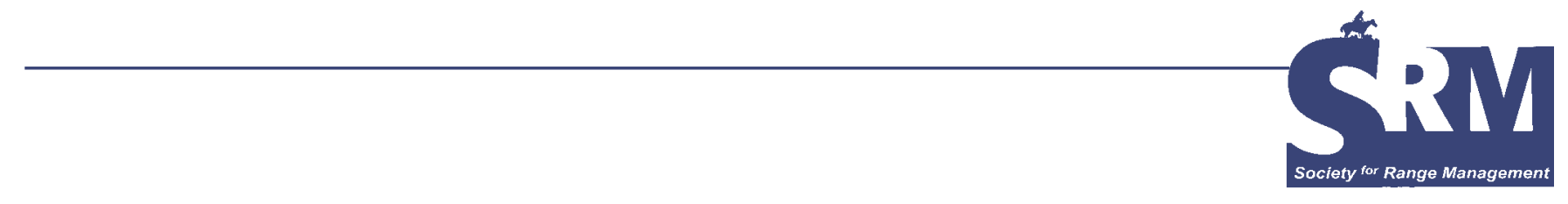

\title{
Central Afghanistan Rangelands
}

\section{A History of Tribal Rule, Grazing, War, and Rebuilding}

\section{By Daniel Robinett, Daniel Miller, and Donald Bedunah}

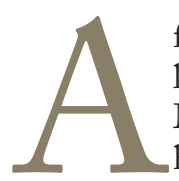

fghanistan, encompassing $63,000,000 \mathrm{ha}$, is a little larger than the states of Arizona and New Mexico combined and has a long history of human occupation. It is a culturally diverse country peopled by tribes of Turkish, Persian, and Mongolian descent. The northern foothills of the Hindu Kush, the major mountain range of Afghanistan, are within the historic range of the domestication of wheat and barley and sheep and goats some 10,000 to $11,000 \mathrm{yr}$ ago. ${ }^{1}$ The grazing of small flocks of closely herded sheep and goats over the last 4,000-5,000 yr has been an important factor in shaping the development of Afghan plant communities. Today rangelands comprise between $60 \%$ and $75 \%$ of the land area depending on the source of the information. These rangelands are critical for supplying Afghanistan with livestock products, fuels for heating and cooking, building materials, medicinal plants, and habitat for wildlife. Rangeland watersheds feed the springs, streams, and rivers, and they are the lifeblood of the country, nourishing nearly 4,000,000 ha of irrigated lands. In this paper we provide an overview of the rangelands of Central Afghanistan and the critical issues and problems regarding natural resource use and rangeland management. To understand the current situation it is necessary to review the historic setting to appreciate how the rangelands were formed and why the current problems are so daunting. As such, we begin with a discussion of Afghanistan's history and describe the natural setting, including geology, geography, hydrology, and climate, as well as agriculture and livestock. We then discuss the Central Afghanistan rangelands of the Hindu-Kush, including aspects of rangeland inventory and range management.

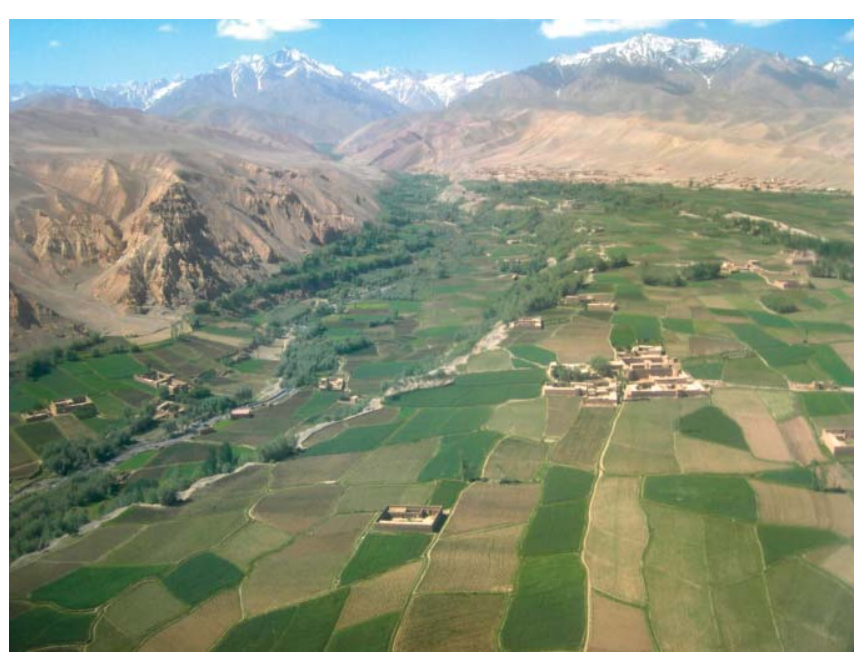

Bamiyan, Central Afghanistan, farmland and rangeland in the Hindu Kush mountains.

\section{Historic Setting}

Afghanistan has a long and interesting history, and although many people have tried to conquer this rugged landscape with its independent tribes, none have been able to control the region for long. Alexander the Great invaded the area in $340 \mathrm{BC}$ and even married a Bactrian princess in the city of Balkh. Genghis Khan conquered the area in $1220 \mathrm{AD}$ and destroyed cities like Ghaznī, Herāt, Mazār-e Sharīf, and Bāmiān. By the 1700s Afghan dynasties, dominated by the Pashtun tribes in the east, began a rule that continued until recent times. During the mid-1800s through the 1900s 
Afghanistan was caught between the British Empire in India and the Russian empire to the north. The country was in the middle of a tug-of-war between the two great powers for nearly $100 \mathrm{yr}$. All present-day boundaries of Afghanistan were forced on the country by the British, the Russians, or a combination of the two. ${ }^{1}$ Russia consolidated its control in Central Asia by incorporating Turkmenistan, Uzbekistan, Kazakhstan, Tajikistan, and Kyrgyzstan into the Soviet Union in the 1920s. ${ }^{2}$ Over the next $50 \mathrm{yr}$ Russian influence in the northern part of the country led to momentous changes in Afghanistan.

Afghanistan was ruled by a royal family. King Mohammad Zahir Shah and Prime Minister Daoud Khan ruled from 1950 through the early 1970s, which was a peaceful and prosperous time. ${ }^{1}$ The king, who returned from exile after the fall of the Taliban, only recently died in late July 2007. Several Americans who lived in Kabul during those times told the principal author that Kabul was the nicest city in all of Central Asia to live and work in and raise a family. It is certainly a different city today!

By the late 1970s communist influence from the Soviet Union resulted in a takeover of the Afghan government. The Russians used military force to prop up the faltering regime in 1979 . For the next 10 yr the country was torn by a violent guerilla war between the Russian military and tribal resistance, known as the mujahedeen, supported by the United States. The countryside was depopulated; large areas were mined; social and political institutions destroyed, and agricultural and industrial infrastructure was damaged. The Russians pulled out in 1989, and the United States' interest in the country also waned. The result was that tribal factions

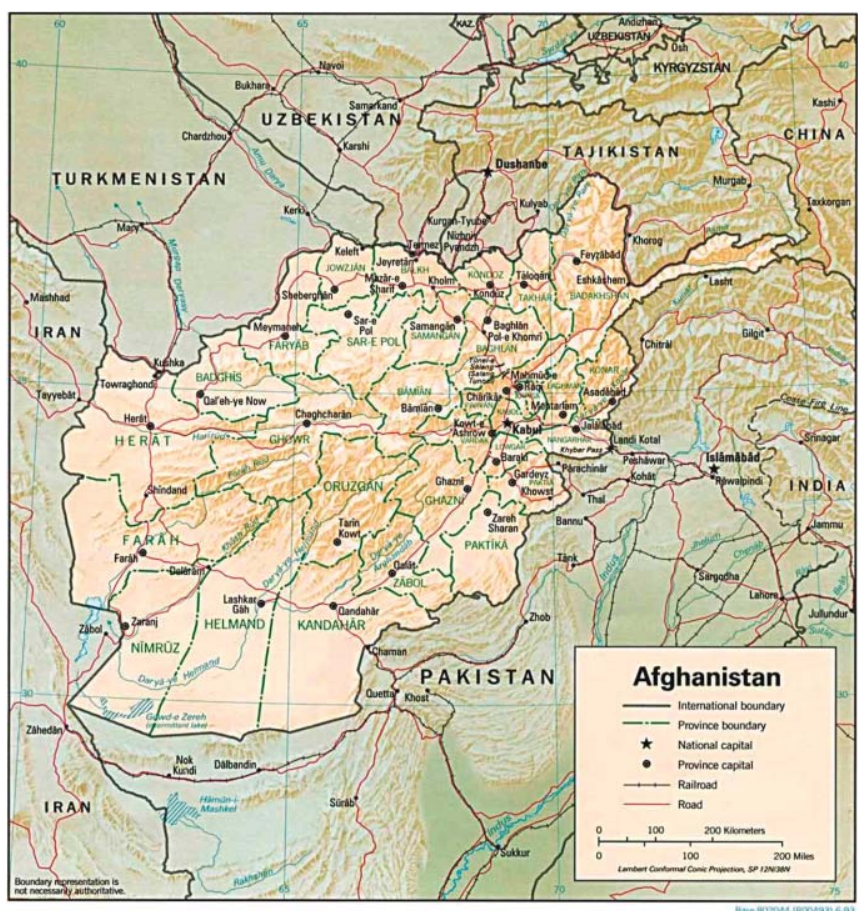

Map of Afghanistan.

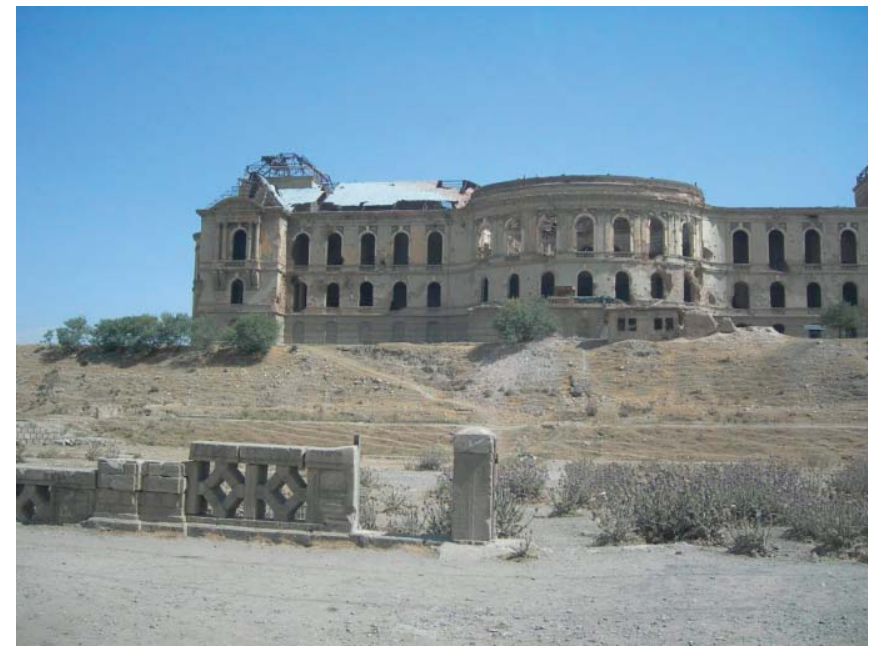

The ruins of Da Ru Laman palace west of Kabul, 2006.

within Afghanistan fought for control of the country, and the country became engulfed in a civil war. Cities like Kabul were shelled into rubble. By the mid-1990s the Taliban had formed and had defeated many of the tribal factions that were fighting in the country. Taliban rule became more oppressive with each passing year. The "Sunni" Taliban brutalized and killed thousands of citizens, but especially hard hit were the "Shi'a" Hazara in the central mountains. Nearly 1,000,000 Afghans died as a direct cause of war during these times and another 1,000,000 were maimed or orphaned. Approximately 4,000,000 left the country as refugees. ${ }^{1}$ Countless others were left homeless and without their land or livestock. Nearly all educated Afghans left the country; some to Europe or the United States, many to Pakistan or Iran. International assistance in the form of skilled personnel, development projects, and educational assistance ceased during this time. Assistance in the form of food and health aid continued to be supported by a few non-governmental organizations (NGOs) and the United Nations.

During the chaos of $10 \mathrm{yr}$ of Soviet war and the following $12 \mathrm{yr}$ of civil war and conflict the infrastructures of the government, education, and agriculture collapsed. In the last few years of Taliban rule universities were led by illiterate mullahs and classes were not even held. An entire generation of students was denied education. In the countryside complex patterns of land tenure, ownership, and water rights were disrupted. ${ }^{3}$ In the absence of law and order local strongmen (warlords) consolidated control over land and resources. From 1997 through 2004 severe drought devastated rangelands, and many rural Afghans lost all or nearly all of their livestock. Of the 2,500,000 nomads in the country over half lost their livestock and either left the country or settled in refugee camps. ${ }^{4}$ Many nomads lost access to historic winter or summer ranges and remain "bottled up" in smaller areas further damaging rangelands. ${ }^{5}$ Through all of this the population of the country increased from 
$15,000,000$ in 1979 to over $29,000,000$ today. Improved foreign assistance in child health care and nutrition has contributed to the population increase as has the return of refugees displaced by drought and fighting.

In 2001, the United States-led international coalition joined with the Northern Alliance resistance fighters to overthrow the Taliban and liberate Afghanistan. The newly formed government under President Hamid Karzai is trying to rebuild the governmental and educational institutions destroyed by decades of war as well as leading an international effort to rebuild the economy of the country. It is proving to be a difficult task. ${ }^{6}$

Today, tribal areas around the Hindu Kush Mountains still retain their customs, language, allegiances, and grievances. From the northeast and counter-clockwise the major tribes include the Kirgiz, Tajik, Uzbek, Turkmen, Aimak, Persian, Balochi, Pashtun, and Nuristani. The Hazara people reside in the high mountains in the center. The religion is Islamic and these tribes are mostly Sunni with the exception of the Hazara, who are Shi'a. Dominant languages are Pashtun and Dari, the latter being a derivative of Farsi (the language spoken in Iran).

In Afghanistan, the family is an important group, and Afghan culture emphasizes loyalty first to family members then clan, tribe, country, and government. The present-day government of Afghanistan is an Islamic republic led by an elected president with a parliament and a judicial branch. A fourth, unwritten, branch of government is that of "paternalistic rule," a powerful political institution of tribal rule now too-often hijacked by strongmen called "commanders" ("warlords" in the western media).

Ministries in the Afghan government appear to be very powerful. The Afghan Ministry of Agriculture and Irrigation (MAI) administers all land and natural resource law and is responsible for land rights, titles to land, legal land survey, and water rights, as well as agricultural extension, reconstruction, training, and enforcement at the national, provincial, and district levels. In the Land Law decree of 2003, the Afghan government claimed ownership of all rangeland and forestland in the country. In reality ministries such as MAI have little power or the resources to enforce their legal responsibilities.

There are five universities in the country with agricultural schools, but facilities are antiquated or in disrepair, and the level of instruction needs improvement. None of the agricultural schools have a curriculum in rangeland management.

\section{Natural Setting}

Afghanistan is a landlocked country with arid deserts to the south, west, and northwest, the monsoonal lowlands of India and Pakistan to the east, and alpine areas of the Pamirs to the northeast. North latitude is from $31^{\circ}$ to $38^{\circ}$; longitude ranges from $61^{\circ}$ to $75^{\circ}$. Elevations range from a low of $250 \mathrm{~m}$ where the Amu Darya (Oxus River) flows into
Turkmenistan to 7,485 $\mathrm{m}$ at the top of Mt Nawshak in the eastern Hindu Kush.

The geology of Afghanistan is defined by the collision of the Indian oceanic plate and the Asian continental plate. The uplift and folding of the Hindu Kush and Pamir ranges is due to this tectonic activity. The Chaman fault runs along the eastern edge of the Hindu Kush from Kandahar through Kabul and forms the base of the Indian plate. The Hari Rud fault runs across the center of the Hindu Kush from Herāt through Bāmiān and marks the boundary of the Asian plate. The rocks are mainly metamorphic (schist, gneiss, slate, and quartzite). Some areas of unaltered sedimentary rocks like sandstone, shale, and limestone remain. ${ }^{7}$

The hydrology is defined by large rivers fed by snowmelt in the spring (March-May). The Amu Darya, Hari Rud, Farah Rud, Helmand, Kabul, and Panjshir rivers all drain from the Pamir and Hindu Kush into the lowlands and out of the country. Hydrographs peak in the spring with occasional heavy floods due to excessive snowmelt and heavy rain. The rest of the year is characterized by low to moderate stream flows. Numerous spring areas exist in smaller drainages, and these are often tapped for irrigation downstream by ancient underground canals and tunnels (kareez).

The climate of Afghanistan is continental. Winters are cold; summers are hot and dry. Virtually all of the moisture comes as snow in the winter and rain in the spring. Only a small area in the mountains along the Pakistan border receives summer rain from the Indian Monsoon. Kabul, at $1,800 \mathrm{~m}$ elevation, lat $34^{\circ} \mathrm{N}$, and with $270 \mathrm{~mm}$ average annual precipitation, has vegetation that looks remarkably

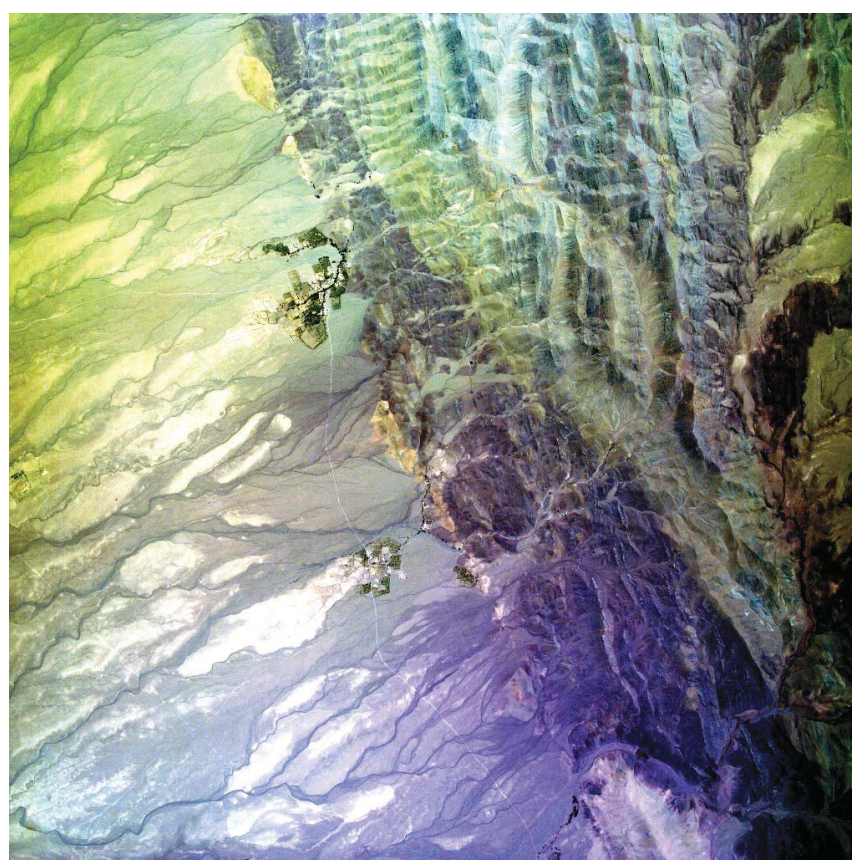

United States Geological Survey photo of the Chaman fault near Ghaznī. 
similar to that of the hills around Reno, Nevada. One author considers this region to be very similar climatically to the Great Basin in the western United States. ${ }^{8}$

\section{Agriculture and Livestock}

Nearly $80 \%$ of the people live in rural areas, and agriculture accounts for $50 \%$ of the gross domestic product. Livestock products are about one-quarter of all agricultural sales. Four million hectares of irrigated lands in valleys produce a tremendous variety of crops. Wheat is the principle food crop. Winter and spring wheat is grown and used to make unleavened bread (nan), the staple food across the country. Alfalfa, rice, beans, vegetables, melons, berries, apples, apricots, grapes, and nuts are all important crops. Fields are small; they are measured in jeribs (0.20 ha), leveled by hand, usually tilled by draft animals, and flood irrigated. Dry-land (lalmi) farming of wheat, barley, and melons occurs in the mountain regions and the northern foothills, and there is concern today that increased dry-land farming is reducing rangelands and leading to increased erosion. Milk from cows is important, and yogurt is a staple and safe food in rural Afghanistan. Most small-farm families have one or two milk cows. Cows are seldom seen and usually kept in the family compounds where feed is brought to them. The offspring are used for draft and beef. Farmers also commonly own small flocks of sheep and goats.

Nomads are a significant part of the rural population of Afghanistan. Prior to war and drought an estimated 2,500,000 nomads ("Kuchi" in Pashtun language) migrated from winter settlements in deserts to the high mountains for summer grazing and back. At present about 1,500,000 Kuchi are still engaged in a nomadic lifestyle with mixed herds of camels, sheep, and goats. ${ }^{5}$ Nomads are mainly Pashtun but also include Aimak, Balochi, Uzbek, Turkomen, and Kyrgiz., ${ }^{4}$ Several hundred thousand Pashtou nomads historically migrated to winter ranges to the east in Pakistan. That border was largely closed to them in the late 1960s and remains so today. ${ }^{1}$ Much of the high mountain country in Bāmiān and Dayikuendi provinces controlled by Hazara people has been closed to Pashtun nomads since 2001. This has happened in response to abuses the Hazara suffered at the hands of the Taliban. ${ }^{3}$

Rangeland livestock are mainly mixed flocks of sheep and goats. Sheep are more numerous and are of the Central Asian "fat-tail" variety (Ovis aries). The common, coarsewool sheep are good meat animals with average size from $65 \mathrm{~kg}$ to $75 \mathrm{~kg}$ for an adult ewe. Trade with Soviet-occupied territory to the north brought improved genetics into the native sheep herds. ${ }^{10}$ Common wool is often left to fall off the animals in the spring because there is poor market for it in the central part of the country. That which is utilized is used for home weaving or sold to yarn producers in large cities like Kabul. ${ }^{11}$

A carpet-wool breed of fat-tail sheep called Karakul is common in Afghanistan, and they are bred for pelts of

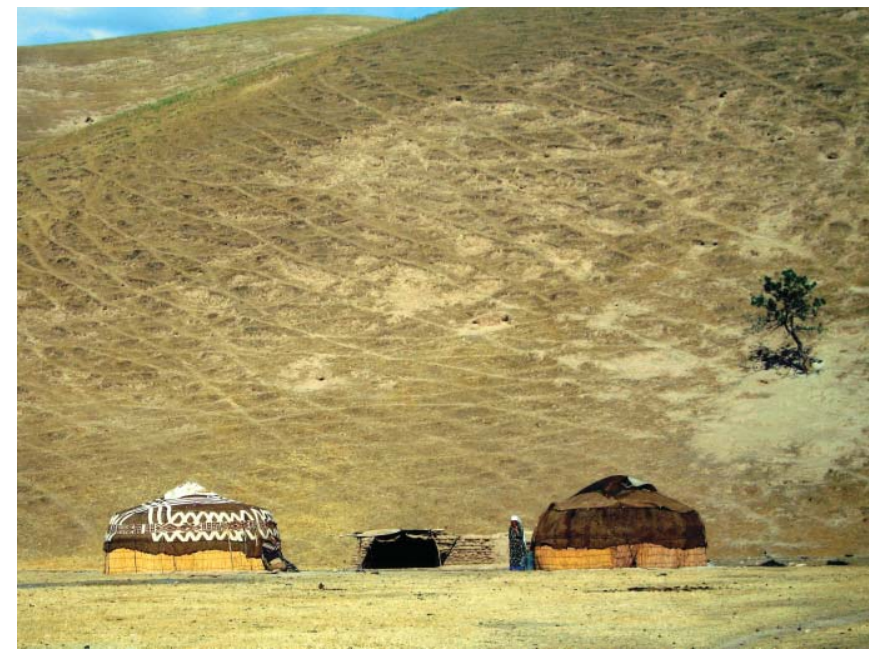

Uzbek nomads in Samangan province.

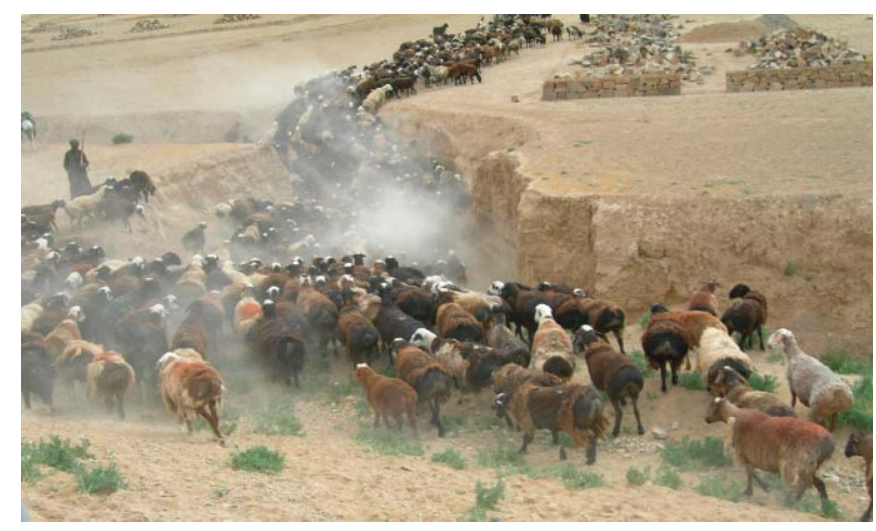

Afghan fat-tail sheep near Chaghcheran.

the newborn lambs, which are used to make vests and hats. The Karakul may be the oldest breed of domesticated sheep and is very hardy, adapted to the harsh environments of Afghanistan. The "Astrakhan" pelt of the newborn lambs was the main agricultural export of Afghanistan before the Soviet war. ${ }^{1}$

Goats are long-haired, dark-colored local breeds. They are hardier than sheep and have higher twinning rates. In western deserts the cashmere that they produce is harvested. ${ }^{11}$ Goat hair is used to make ropes and felt for tents and yurts (rounded, tent-like structures). The meat is eaten and used to make jerky. Goats are often used to lead the flocks of sheep.

Camels are the beasts of burden for the Kuchi. The onehumped, dromedary type is common across the country. Bactrian (two-humped) camels are found in the northeast in the Pamir mountains. Camels carry heavy loads and according to local herders can eat even the spiniest shrubs and herbs left by small stock. Donkeys and horses are the beasts of burden for village people. Carts pulled by animals are seen everywhere in the country, and water is almost always packed on donkeys. Oxen (steers of dairy breeding) are used 
for draft in most rural areas to plow and cultivate. Only larger farm operations use tractors.

Cattle are seldom seen on rangelands because people prefer sheep and goats as a meat source, and many of the rangelands are better used by small animals. When cattle are seen on rangelands they are in small herds of small, native breeds. Markets, however, do exist in larger cities like Kabul and Jalalabad, where fattened steers and water buffalo bullocks (from Pakistan) are slaughtered for beef. ${ }^{11}$

Livestock numbers are difficult to estimate. Many rural people will not fully report their numbers to avoid taxation and government intrusion. The last livestock census conducted by the UN Food and Agriculture Organization was in 2003 (after high drought mortality), and the herds have undoubtedly grown with good precipitation in 2005, 2006, and 2007. In 2003 there were 15,000,000 sheep and goats, 4,000,000 cattle, 1,600,000 donkeys, 140,000 horses and 175,000 camels. ${ }^{9}$ Range livestock are essential to the agricultural economy of Afghanistan and the survival of rural people.

\section{Rangelands in Central Afghanistan}

Rangelands in the central region occur across the Hindu Kush at elevations from $1,000 \mathrm{~m}$ to $4,000 \mathrm{~m}$ and with mean annual precipitation ranging from $150 \mathrm{~mm}$ to $500 \mathrm{~mm}$. The natural vegetation across most of this region is sagebrush steppe with large areas capable of supporting open woodlands of juniper (Juniperus seravschanica, J. excelsa, J. semiglobosa) or pistachio (Pistacia vera, P. atlantica).

These lands produce seasonal grazing for Kuchi and their herds as well as opportunistic grazing for villagers throughout the region. They also exist as vast watersheds that capture snowmelt and recharge stream and spring-flow throughout the country. These rangelands produce a tremendous variety of plants for medicinal uses, wildlife habitat, food, shrubs and trees for fuel and building materials, and soil for adobe bricks. The diversity of plants is high. The herbarium at Kabul University had over 60,000 voucher specimens representing nearly 4,000 species of plants. Unfortunately the herbarium was destroyed during the civil war in the 1990s.

Existing plant communities are well adapted to heavy utilization because livestock grazing has occurred for 4,0005,000 yr. Perennial grass, grass-like species, and herbs exhibit many adaptations to close grazing. Bulbs, rhizomes, rootstocks, dormant seed, awns, and barbs are common. Hundreds of herbaceous annual species occur in these plant communities. Several annual grasses that have become serious North American weeds, including cheatgrass (Bromus tectorum), medusahead (Taeniatherum caput-medusae), and goatgrass (Aegilops crassa), are native to this environment.

Shrubs tend to be well armed with thorns or spines or have high levels of toxic substances or essential oils like alkaloids and terpenes.

Several species of juniper and two species of pistachio occur in this region. These low trees presently exist in isolated areas but formerly had much more extensive ranges. ${ }^{12-14}$ The harvest of wild pistachio nuts is very important economically to the communities where the forests are found.

Soils across Central Afghanistan are nearly all calcareous, primarily as a result of secondary enrichment by carbonates from wind-blown dust. The soil moisture regime is xeric and temperature regimes range from thermic to mesic (frigid at the higher elevations). Shallow to moderately deep $(25-60 \mathrm{~cm})$ soils occur on hill slopes. They are moderately dark colored on the surface $(8-10 \mathrm{~cm})$ and are gravelly sandy-loams. These soils are classed as haplocambids or haplocalcids. Some relict soils with argillic horizons occur on moderate slopes in these ranges. Parent materials are metamorphic rocks like schist and gneiss.

Deep soils occur in valleys and appear to be mixtures of loess and gravely stream alluvium. Textures are silty; gravel content is variable. They are calcareous, yellow in color, and classified as haplocambids. Soils in bottoms are usually cultivated and silt-loam to silty-clay in texture. Many have high water tables and salts at various depths.

Plant communities across this region appear simplified in areas close to cities and villages. Intense human use of these lands during the last $23 \mathrm{yr}$ of war, drought, lawlessness, and population increase has resulted in the loss of shrub and tree cover and in plant communities dominated by annual grasses and forbs. But, upon closer inspection, many are surprisingly diverse, especially the plant communities of rocky hill sites. Areas of these sites in the Paghman district near Kabul often had 40-50 species of shrubs, perennial grasses, and forbs as well as a host of ephemeral species. Biomass (dry weight) production on one site in this area was $450 \mathrm{~kg} \cdot \mathrm{ha}^{-1}$ in the spring of 2006 with average moisture. This was before the end of the growing season. A soil transect in this same area showed soil depths from $25 \mathrm{~cm}$ to $60 \mathrm{~cm}$ (to weathered schist bedrock) with dark-colored mollic surfaces $8-10 \mathrm{~cm}$ thick. The soils were very gravelly and calcareous. Soil erosion did not appear to be accelerated on these

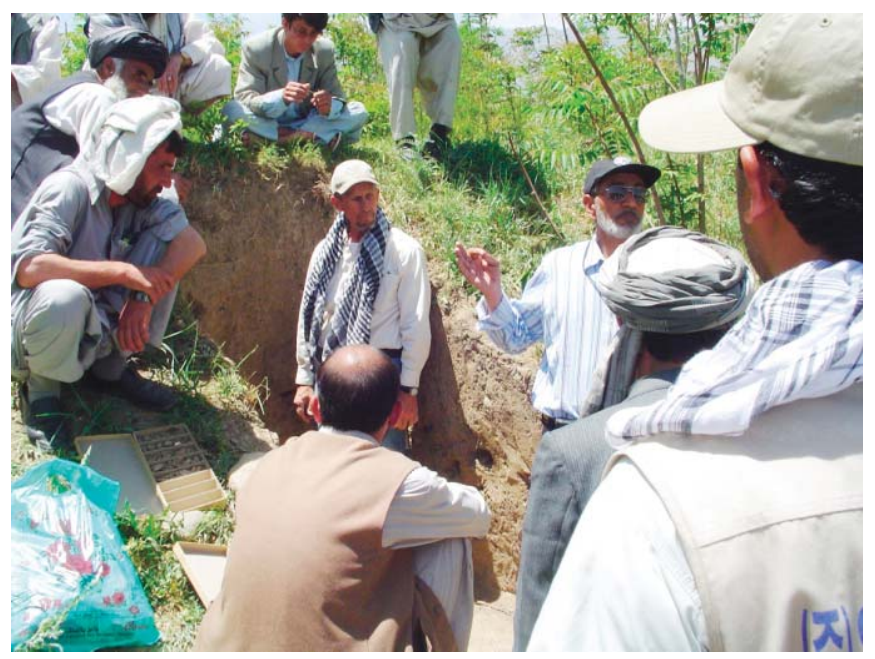

Deep, silty soil near Paghman, Kabul province, May 2006. 
gravelly slopes even with intense livestock grazing from nearby villages as well as Kuchi flocks.

Rangeland areas immediately adjacent to villages are affected by sheet and rill erosion. Soil compaction and loss of plant cover is extreme due to the daily movement of small livestock herds. Open range areas, even when heavily grazed, often show few signs of accelerated erosion. The nature of the precipitation, snow and gentle rain, does not appear to drive significant hill-slope erosion unless soils are heavily compacted. Observers in other areas have reported some evidence of sheet and rill erosion, especially in hilly woodlands. ${ }^{15}$

Significant gully erosion occurs in nearly all of the deep soils of the valleys, and bank erosion is common along rivers and streams. Concentrated flow from spring snow melt, compacted soils, and little or no plant cover has resulted in severe gully erosion across the central region.

It is difficult to find plant communities that might resemble some stable assemblage of species at equilibrium with the environment. The security situation and the presence of land mines restrict travel, and there are few areas that are not heavily used by livestock. Religious sites like shrines and cemeteries often have less use. The ziarat (saint's shrine or holy place) vegetation in these sites is often grazed, but shrubs and trees are not molested due to superstitions about spirits (jinn) that reside in the plants. ${ }^{12,14}$ Several village shrines visited by the principal author had dense stands of two or three Artemisia spp., other shrubs, and many perennial grasses and herbs. Two ecological site descriptions were developed from information gleaned from these areas and rangeland on Government nurseries (producing trees for greenbelts and reforestation).

Common perennial grasses and grass-like species on upland sites include Poa, Elytrigia, Festuca, Aristida, Stipa, Agropyron, and Carex. Common herbs are numerous with members of the poppy (Papaveraceae), legume (Febaceae), sunflower (Asteraceae), borage (Boraginaceae), lily (Liliaceae), and mint (Lamiaceae) families. Shrubs include several species of Artemisia (A. diffusa, A. herba-alba, and A. turanica), Amygdalis, Karelina, Tamarix, Alhagi, Ephedra, Acanthophyllum, Acantholimon, Lycium, Caragana, Salvia, and Ceratoides. Annual grasses include several species of Bromus, Schismus, Hordeum, Vulpia, Eremopyrum, Taeniatherum, and Aegilops.

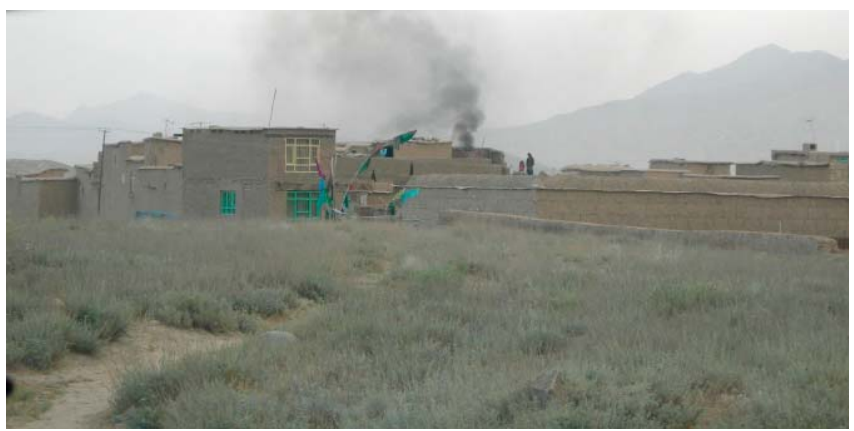

A. diffusa and $A$. turanica at Dodemast village shrine.

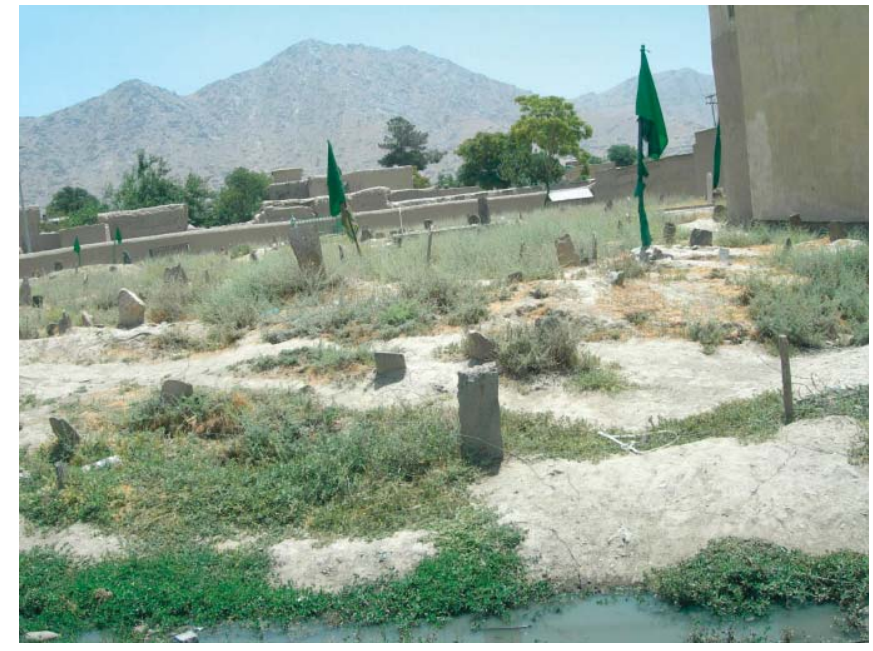

A. herba-alba at Ghuzargha village cemetery.

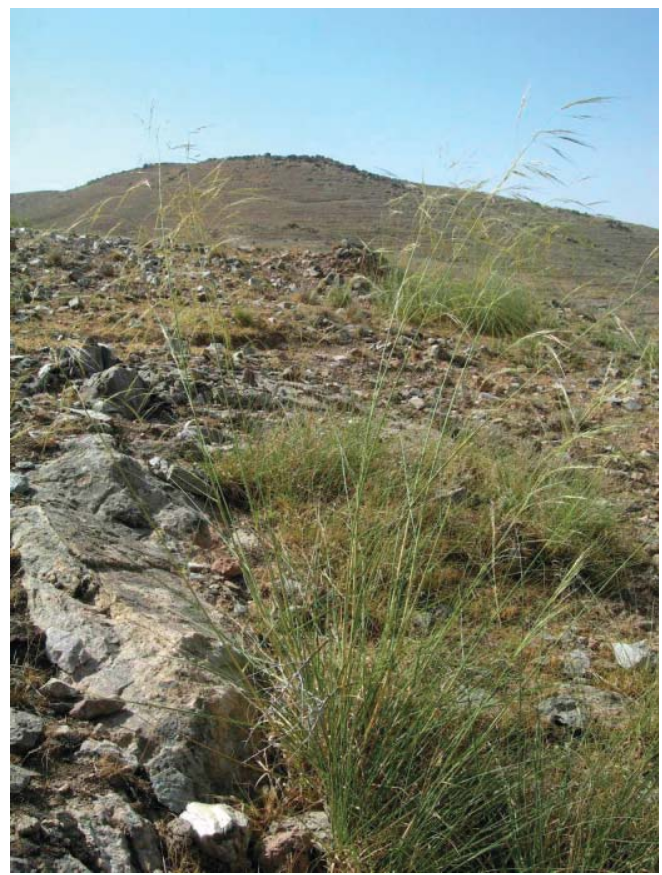

Aristida, Stipa, and Carex spp. near Kabul, June 2006

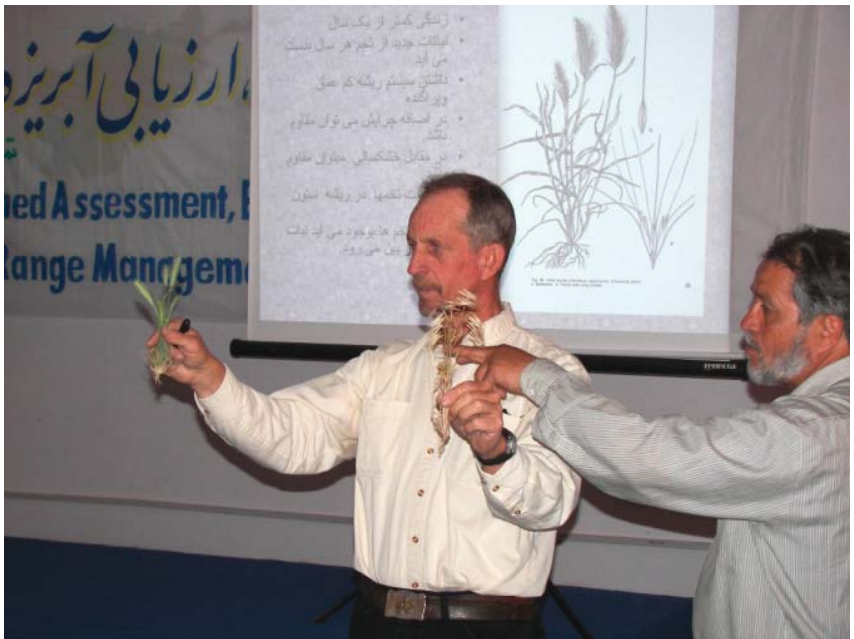

Native annual grasses, Hordeum leporinum and Bromus tectorum. 
One subshrub of note is Peganum harmala ("asfang" in the local vernacular). This highly toxic plant is common on most barren and overgrazed land near villages and water locations. It cannot even be used for fuel because the smoke is poisonous, although it is used to fumigate houses to kill bedbugs and lice. It has been found in southern New Mexico as a range weed and could become a serious problem if it finds its way into the Great Basin.

Juniper and pistachio occur across central Afghanistan. From studies of the present range of these species most authors agree that suitable habitat for them is many times larger than the presently occupied habitat. In one study in Samangan province Pistacia vera is thought to occupy only $5 \%$ of its historic range, and the half of the remaining stands had been cut over in the last $30 \mathrm{yr}^{15}$ These tree species occur in the northern and southern foothills of the Hindu Kush. Thousands of years of harvest for fuel and construction materials have removed trees from most of their historic range. ${ }^{14}$

Sagebrush or Artemisia spp. fill a dominant niche in these xeric and intensely grazed environments. The essential oils in sagebrush (terpenes) inhibit rumen microflora and greatly reduce the digestion of cellulose. Many species are not grazed at all during the growing season but are used a little after hard freezes in the winter. A few species are more palatable (A.turanica) but still able to thrive under the historic grazing patterns.

Shrub cover is extremely important to provide soil protection, to trap snow on the land, to shade the soil surface, to provide wildlife habitat, to develop rooting structure, and to break up soil compaction. The present-day utilization of sagebrush for fuel is not sustainable and is one of the most pressing problems in rangeland management in Afghanistan. The value of sagebrush to future generations of Afghan people for use as fuel should be a huge concern, and its conservation should be given more attention.

Winters in Afghanistan can be quite cold and long, and fuel for heating and cooking comes mostly from wood,

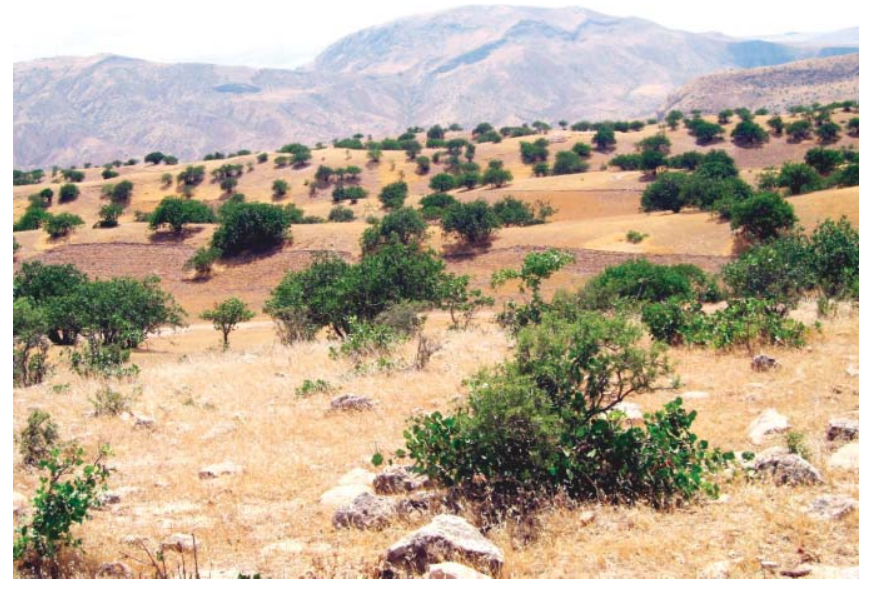

Pistachio woodland in Samangan province. shrubs, straw, and dung. Electricity and propane for heating and cooking are available in urban areas; however, even in the largest cities many people have to use rangeland fuel sources because propane is expensive, and electricity is only intermittently available. Artemisia spp. have been utilized for centuries but the widespread clearing of areas appears to be a recent phenomena. The loss of these shrubs on steppe rangelands reduces their productivity and allows snow to blow off of unprotected slopes. At the Criminal Police Station in Chagcharan (Ghor province) the pile of sagebrush needed to supply 15 officers, a cook, and housekeeper for the winter was $20 \mathrm{~m}$ in diameter and $3 \mathrm{~m}$ high. Trucks and chopping crews bring sagebrush fuel into the cities from far out on the ranges. There is often armed conflict among villages in remote areas over access to the remaining stands of sagebrush and other shrubs. A doubling of the rural population, lack of local control over access to resources, and poor plant recovery due to overgrazing and drought has made the situation much worse. This is occurring across much of Central Asia and the Middle East. ${ }^{16}$

In the northern foothills of the Hindu Kush and increasingly at higher elevations, rangeland is being plowed for grain or melon crops. Most of this is subsistence farming near small and poor villages but large areas are being plowed on the part of local commanders in "land grabbing" attempts.

On plowed rangeland the native plant cover is destroyed, and protective gravels and soil crusts are broken, and because plowing is seldom done on the contour, water erosion accelerates. Some plowed areas are planted once or twice and then abandoned. These areas also become open to weed infestations. It is not uncommon to see patches of Russian knapweed (Acroptilon repens), hoary cress (Cardaria draba), and other tough perennials (that are toxic or very unpalatable) growing in these areas.

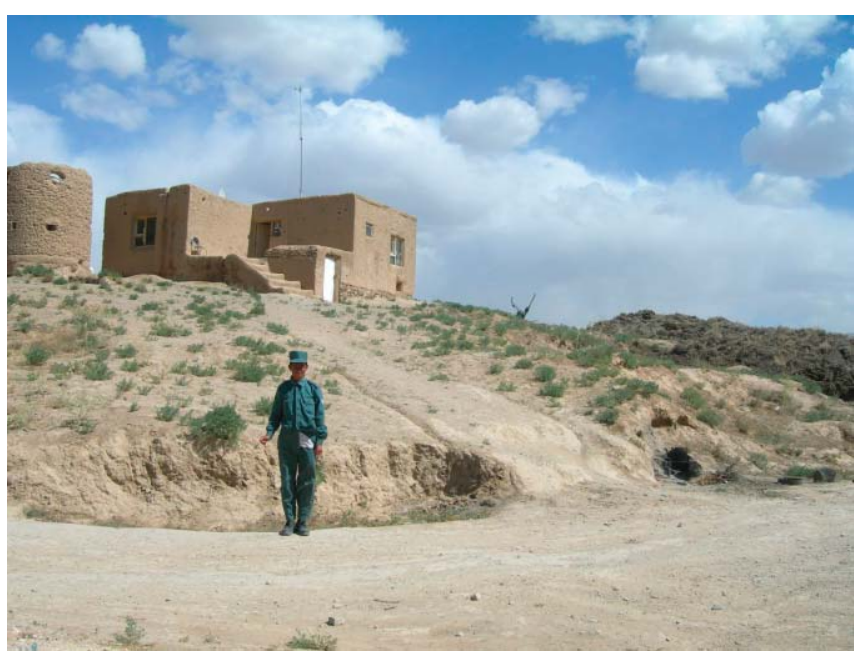

Sagebrush piled for fuel (center right) at the Criminal Police Station in Ghor province. 


\section{Rangeland Inventory}

Very little information exists about the nature and status of Central Afghan rangelands. Some work has been done in the western deserts, ${ }^{5}$ and considerable work has been done to the north in the former Soviet republics (especially Uzbekistan) that can be built upon for future work in Afghanistan. ${ }^{16}$

At the experimental nursery and dairy at Ghuzargha, the Afghan MAI had located offices and labs that housed and assembled land mapping information (plant species and plant communities, life zones, species ranges, wildlife habitat, cropping, and grazing patterns). More than $10 \mathrm{yr}$ of effort was lost because these facilities were destroyed in the civil war.

Prior to the Soviet invasion a number of German and French botanists worked in the country for many years, and information exists on the flora and life zones within the country. Published botanical reports and natural resource maps are a beginning for rangeland inventory in the country. ${ }^{9,12-14,17,18}$ Systematic soil surveys have not been done outside of cropped areas. In May and June 2006 training in range inventory and analysis and the development of range technical guides was provided to MAI staff at both the national and provincial levels, and some training in soil classification and soil-vegetation relationships was provided to both ministry staff and the agricultural college at Kabul University. The Afghan MAI has developed a project proposal with emphasis on improving rangelands; when funded, it will entail an inventory of all rangelands in the country. However, the MAI will need additional technical assistance when that effort begins.

The universities need assistance in developing rangeland management curriculum. Work with the agricultural and veterinary science colleges is ongoing at Kabul University, and one soils professor is now in the United States for a year of advanced training at Purdue University.

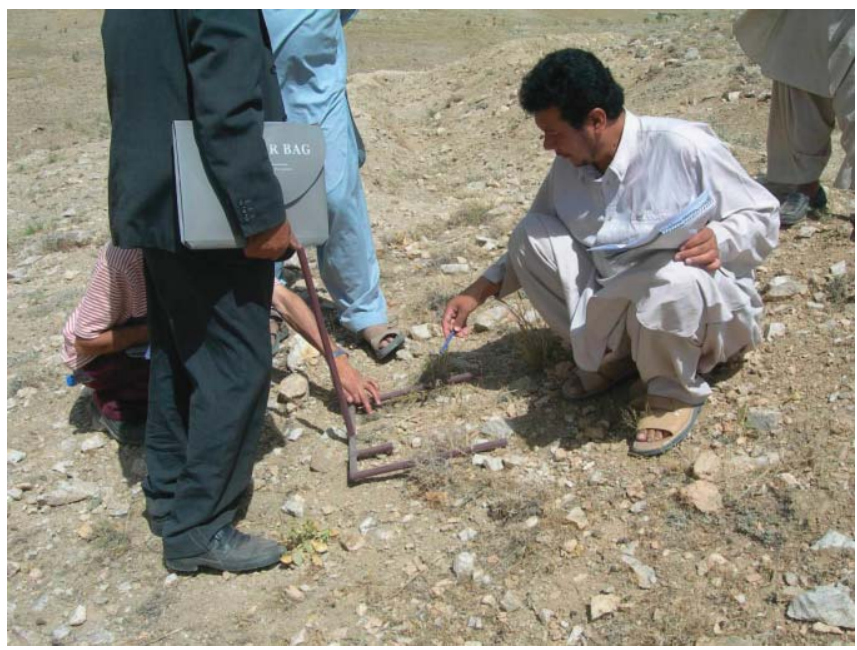

Rangeland inventory and monitoring class at Qargha, Kabul province, June 2006.

\section{Rangeland Management}

Improving the management of Central Afghan rangelands and woodlands will be a long-term effort. It will involve years of education, training, inventory, assessment, research, extension, and collaborative work with both communities and nomads as well as formulation of laws/policies that provide for sustainable use. The Afghan MAI has wisely adopted an official policy of community-based land management, but improved management will only happen in a secure and nonthreatening environment. The continued violence and insecurity is a threat to improved management of Afghanistan's rangeland resources.

Nomads are estimated to own $30-50 \%$ of the nation's small livestock. ${ }^{5}$ Their contribution to the national agricultural economy is very important. Kuchi can exploit marginal lands and rangeland in very remote areas. Their livestock products are important to local economies, and they provide a source of inexpensive labor for farmers in larger communities. They also engage in trading and gathering fuel for sale in villages.

In the southern foothills of the country, the Kuchi have recently been restricted to their traditional spring and autumn ranges. Denied access to historic winter areas in Pakistan and now denied access to high-elevation, summer ranges in the Hazarajat (the high plateau of the Hindu Kush), many Kuchi have little choice except to continue to use these ranges year-round, resulting in extreme overgrazing. Kuchi usually camp within a half-day walk to water. Livestock are herded out each day as far as possible and return to camp each night. A Kuchi family is now forced to stay in an area until all the forage is depleted. The principal author saw children digging roots of annual grasses and forbs and collecting sheep dung in June for fuel.

Ministry staff often said that the Kuchi will not move until the land is turned to dust. Rangeland areas that villages had tried to defer from grazing to promote rangeland recovery were grazed by nomad herds. Under the

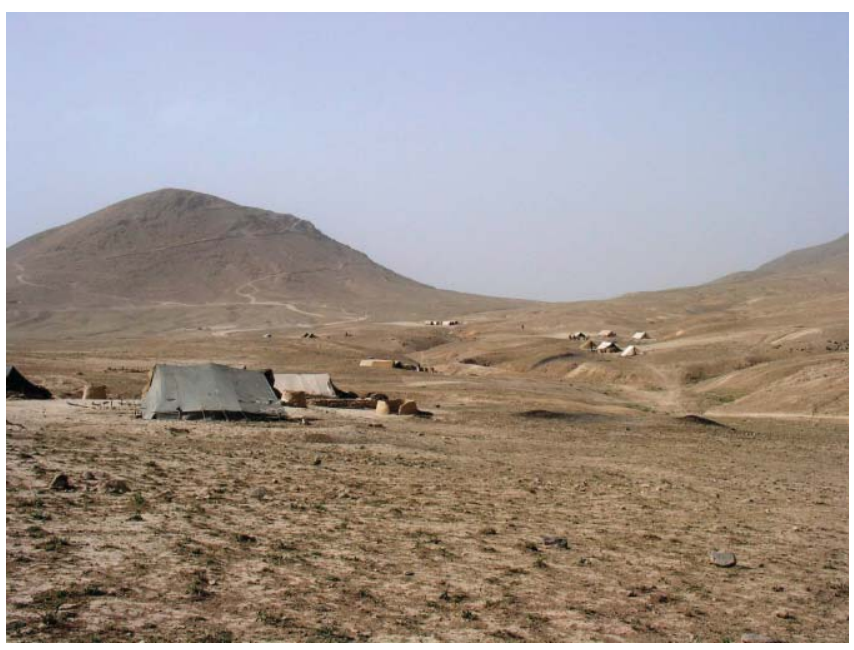

Kuchi (nomad) camp in Kabul province in heavily grazed rangeland. 
present-day conditions of limited access and disruption of both formal and informal land-use agreements, the pressure on rangeland is extreme.

A Pastoralist Support Strategy has been proposed to the Afghan MAI and the Ministry of Tribal Affairs. Programs to help provide alternative income sources, provide access to a wider variety of rangeland, adjudicate grazing rights and maintain the culture of nomads are needed to solve the many problems in management of nomadic grazing. ${ }^{5}$

Grazing by herds from villages and around cities is opportunistic. Animals are herded onto adjacent rangelands as soon as green forage is available in the spring, and these areas (within a day walk to and from the village) are used until forage runs out in the summer or autumn. Much of the livestock feed for village animals is produced on farmlands or consists of weeds growing along field borders and ditch-banks. Many Afghan MAI staff own small herds of livestock and farm small plots. Several said that they knew that there were far too many animals in their village for the surrounding rangeland to support. They asked how they could attempt any improvement in range management under such circumstances. After much thought and discussion, one approach that some agreed might work was to provide basic training in the principles of range management to the community and then work with the village "shura" (village council) to agree to focus on a small part (10\%) of the lands they control. This area would be deferred for several years in the growing season (April-August) and grazed in the fall and winter. Seeds from important forage, fuel, and medicinal species could be collected and planted in snow in the rested area. Since all livestock are herded, grazing could be easy to control. This could demonstrate, on a small scale, the benefits of improved rangeland management.

Several organizations working in Afghanistan realize the importance of better rangeland management in improving rural livelihoods and human health and nutrition. Some are beginning to tie the receipt of social services and other aid to training in natural resource management and guidance for locally lead efforts to rehabilitate rangelands. NGOs, e.g., Catholic Relief Services in Herat and Ghor provinces, are working in this manner and have even trained and equipped Afghan MAI extension employees to do the work. In other areas, organizations, e.g., Food and Agriculture Organization (FAO) of the United Nations, Aga Khan Foundation, Mercy Corps, and Madera, are using the same approach at the community level. Many of these organizations had field staff that attended the June 2006 training in rangeland management and inventory which the principal author conducted.

Complex and localized patterns of rangeland ownership and communal rights existed in Afghanistan before the Russian occupation. Soviet attempts at collectivization of agriculture, the subsequent free-for-all after their retreat in

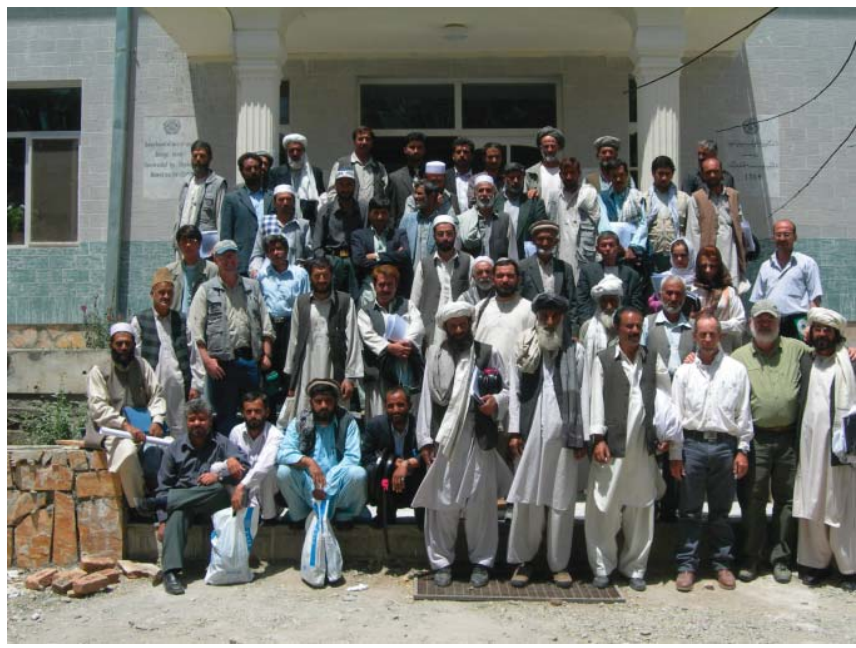

Afghan Ministry of Agriculture and Irrigation employees and trainers in May of 2006.

1989, and the civil war that followed usurped these systems across the country. The FAO is working in Bamiyan province to re-establish these systems so local communities can (once again) control access to natural resources and begin the task of rangeland improvement. Legal documents called "custodial use agreements" are being developed by the Afghan MAI and local communities. These papers recognize local control, have expectations for good land management, and do not preclude the government claim to ownership of the land. Communities are making initial attempts at improving the condition of rangelands by deferring areas from grazing and seeding important perennial plants into denuded areas.

The Afghan MAI has implemented several projects that involve direct seeding or planting of pistachio seedlings in suitable habitat within its historic range. A variety of sources fund this work, and all projects employ local labor managed by the Afghan Conservation Corps (ACC) with expertise and guidance from skilled foresters working for the Afghan MAI and the ACC.

A final example emphasizes the importance of the role of the Afghan community in the process of implementing improvements in rangeland use and management. A shura from a group of communities in Badkhis province attended a week-long training program in rangeland management. While discussing range deferment, several questioned the idea. In their area, open woodlands of juniper and pistachio are very important to the villages. They described what happened across the border in the Badkhiz Reserve ${ }^{10}$ in southern Turkmenistan. With the exclusion of humans and their herds in the protected area, fires had burned and destroyed large areas of trees. In their area they felt they must graze the early growth of annual grasses like cheatgrass to minimize the fire hazard. They could do this and still defer in late spring and summer to benefit perennial grasses, forbs, and shrubs. 
Severe drought across Central Asia (1997-2004) resulted in catastrophic loss of livestock and lowered range condition. In northern and western Afghanistan, $70 \%-80 \%$ of domestic livestock perished. Planning for drought is important in any proposals for improving rangeland management. Climate studies are becoming more sophisticated in forecasting drought in this region. The best short-term strategy is improved grazing management. Perennial forage plants in good vigor can best withstand short-term drought. A forage reserve created by grazing and then resting areas can maintain animal health and condition for up to a year during drought. Long-term drought causes impacts beyond the control of anyone, but government aid programs should (at least) consider assistance that allows rangelands to recover before being fully restocked.

There are many examples of efforts in rangeland and woodland management and protection that have not worked. In almost all cases it is because of a lack of law and civil order in the countryside. It is one thing for Afghan MAI officials to risk their lives to try and resolve conflicts over competing or illegal uses of the land; it is quite another thing to have effective law enforcement to back them up! In too many situations the man with the most guns wins.

\section{Conclusion}

Afghanistan is a poor country, but it is rich in diversity of cultures and environments. The people are tough, resilient, smart, loyal, and friendly. The natural resources found on rangelands and woodlands in the country are vital to the survival of communities and nomads as well as to the national economy.

The many years of war, drought, emigration, and chaos have devastated both human and natural resources of Afghanistan. This has led to a loss of the traditions of natural resource use and allocation and a generation of uneducated or certainly an undereducated population. There is no doubt that training and improved education is critical and will have to come from foreign donors to help improve land use. An international coalition led by the United States is assisting the government of Afghanistan in the struggle to restore security, rebuild infrastructure, develop markets, and provide education, but this will be a long-term effort.

The Afghan government and agencies like the Afghan MAI are bravely trying to rebuild the institutions and capacity to effectively manage the natural resources in the country. Rangeland management is recognized as an important part of this effort. This will be a long and difficult process. With greater help from the international community the rangelands of Afghanistan could be restored.

\section{Acknowledgments}

The principal author would like to extend his appreciation to the personnel of the Afghan MAI, Department of Natural Resource Management, and to the ACC for their friendship, assistance, and guidance during his stay. The photos of Samangan rangelands are by Linda Norgrove, United Nations Office for Project Services, Afghanistan, Program Manager of the ACC. All other photos are by the authors.

\section{References}

1. Dupree, Louis. 1973. Afghanistan. Princeton, NJ, USA: Princeton University Press. 760 p.

2. Omrani, B., and M. Leeming. 2005. Afghanistan: a companion guide. Hong Kong: Odyssey Books and Guides. $767 \mathrm{p}$.

3. Wily, L. A. 2003. Land rights in crisis, restoring land tenure security in Afghanistan. Islamabad, Pakistan: The Afghanistan Research and Evaluation Unit (AREU), paper 1.152 p.

4. Afghan Ministry of Rehabilitation and Development and the Afghan Ministry of Tribal Affairs. 2004. Kabul, Afghanistan: National Multi-Sectoral Assessment on Kuchi. Unpublished report. 113 p.

5. de Weijer, F. 2005. Pastoralist support strategy. Kabul, Afghanistan: Rebuilding Agricultural Markets Program, US Agency for International Development. Unpublished report. $47 \mathrm{p}$.

6. Katzman, K. 2005. Afghanistan: post-war governance, security, and US policy. Washington, DC, USA: Congressional Research Service, US Library of Congress. Report RL 30588. $55 \mathrm{p}$.

7. Gleason, G. 1997. The central Asian states, discovering independence. Boulder, CO, USA: Westview Press. 220 p.

8. LeHouerou, H. N. 2004. An agro-bioclimatic classification of arid and semiarid lands in the iso-climatic Mediterranean zones. Arid Land Research and Management 18:4.

9. Thieme, O. 2000. Afghanistan, country pasture/forage resource profiles. Rome, Italy: Food and Agriculture Organization Report. 132 p.

10. Kharin, N. 2002. Vegetation degradation in central Asia under the impact of human activities. Dordrecht, The Netherlands: Kluwer Academic Press. 182 p.

11. Thompson, E. F., P. Снавот, and I. A. Wright. 2005. Production and marketing of red meat, wool, skins and hides in Afghanistan. Davis, CA, USA: Macauley Research Consultancy Services and Mercy Corps, Unpublished report. $56 \mathrm{p}$.

12. Breckle, S. W. 1983. The temperate deserts and semitemperate deserts of Afghanistan and Iran. In: N. West [ED.]. Temperate deserts and semideserts. New York, NY, USA: Elsevier Scientific. p. 271-319.

13. Alam, M. 2003. A short survey of the botanical bibliography of Afghanistan. Bulletin de la Societe Vaudoise des Sciences Naturalles 88:3.

14. Freitag, H. 1971. Studies in the natural vegetation of Afghanistan. In: P. H. Davis, P. C. Harper, and I. C. Hedge [EDs.]. Plant life of south-west Asia. Edinburgh: Royal Botanical Garden. p. 90-106.

15. Shovic, H. 2005. Pistachio woodlands temporary duty station-2. Kabul, Afghanistan: USDA-USFS for US Agency for International Development Report. 48 p.

16. Gintzburger, G., K. N. Toderich, B. K. Mardonov, and M. M. Mahmudov. 2003. Rangelands of the arid and semiarid zones in Uzbekistan. Paris, France: International Center for 
Agricultural Research in Dry Areas, CIRAD-ICARDA. $426 \mathrm{p}$.

17. Alam, Mohammad. 2004. Trees, shrubs and some subshrubs of Afghanistan. Bulletin de la Societe Vaudoise des Sciences Naturalles 89:1.

18. Bedunah, D. J. 2006. An analysis of Afghanistan's rangelands and management issues for the development of policy and strategies for sustainable management. Kabul, Afghanistan: Rebuilding Agricultural Markets Program, US Agency for International Development. Unpublished report.

Authors are Range Management Consultant (CPRM), Robinett Rangeland Resources, 16700 N Forecastle, Tucson, AZ 85739, USA,drobinett_az@msn.com (Robinett); Project Development Officer, US Agency for International Development (USAID), New Delhi, India (Miller); and Professor, Range Resources, University of Montana, Missoula, MT 59812, USA (Bedunah).
The lead author was funded by USAID through a Participatory Agency Service Agreement with the US Department of Agriculture (USDA) to work with the Afghan MAI for 4 mo in 2006 on basic training in Rangeland Management and development of Rangeland Technical Guide materials. The Natural Resources Conservation Service (NRCS) of USDA supported this mission. The Foreign Agricultural Service of USDA managed the program and provided logistical support. The information and views presented in this article are solely those of the authors and do not necessarily represent the views or positions of USAID of the US Government. At the time of research, Robinett was a Rangeland Management Specialist, USDA-NRCS; Miller was Agriculture Officer, USAID, and spent 2 yr working in Afghanistan from 2004 to 2006; and Bedunah worked in Afghanistan in November 2005 on an assignment for USAID and in 2006 and 2007 for the Wildlife Conservation Society on a USAID-funded project. 